\title{
Private Tutoring in English Through the Eyes of Its Recipients
}

\author{
Monika Černá \\ University of Pardubice, Faculty of Arts and Philosophy
}

\begin{abstract}
The individualistic nature of learning nowadays, coupled with the global spread of English, has contributed to the rise of shadow education in English. This study focuses on one of its forms, one-on-one private tutoring in English (PTE); more specifically, it explores this privately purchased service through the eyes of its recipients, learners of English. The aim of this study is to uncover the nature of the PTE that the learners experienced and the perceived role of this type of education in their lives.

The study investigates the learners' lives from early childhood to their entry to university, deploying a narrative interview as a data-gathering instrument. Twenty respondents were interviewed; then the qualitative analysis of the interviews was conducted using open coding.

The findings of the study suggest that PTE supplements formal education in the course of the students' lives. Its role in learners' lives is linked to remedial or enrichment purposes. Children's involvement in PTE is initiated either by their parents or by the children themselves for a variety of purposes reflecting all kinds of their needs. Concerning those who provide PTE, they constitute a diverse group including both native and non-native speakers of English; however, nothing is known about them and about the quality of their service. Furthermore, the study identified two specific features of PTE: the demand for PTE for primary school pupils and the phenomenon of the native speaker tutor.
\end{abstract}

Keywords: shadow education, private tutoring in English, one-on-one tutoring, qualitative research, narrative interviews, recipients

Learning nowadays happens in various contexts. It is "far more individualistic, in terms of its form and its content and purpose" (Biesta, 2006, p. 18). This individualisation of learning has led to "a rapidly growing market for nonformal forms of learning" (Biesta, 2006, p. 18), which, in terms of English, is coupled with its global spread as a lingua franca of international communication. Consequently, the English language is found to be the most popularly enrolled subject, especially in countries where it is learnt as a second or foreign language (Yung, 2019), with the Czech Republic being no exception. Hamid et al. (2009) even propose that private tutoring in English (PTE) is "a special and important subclass of private tutoring [...] a macro-phenomenon of modern education" (p. 282). Languages have always had their economic value; Díaz (2015) argues, however, that the scope of the commodification of languages has increased in the world since languages have become a benefit or an asset to job seekers globally. Analysing recent developments in France, Díaz (2015) 
60 uncovers the commodification of English through advertising campaigns - English is represented by images that link knowledge of this language to success, i.e. to a higher salary and better job. Referring to PTE in Bangladesh, Hamid et al. (2018) propose "a silent competition between the curricular and non-curricular sectors" ( $p$. 871), the former being challenged in maintaining the status quo as the latter gains more ground. These examples from two different countries provide evidence that PTE has become a significant part of educational systems that cannot be ignored by educational researchers and policymakers.

This article aims to explore private tutoring in English (PTE) in the Czech Republic through the eyes of its recipients. First, the topic is linked to the broader context of shadow education; then the research on PTE is reviewed, followed by an introduction to the Czech context of the study and the study itself. Finally, conclusions shedding some light on PTE are drawn.

\section{Private tutoring}

Around the world, a significant number of students receive some type of private tutoring (Yung, 2019). This widespread phenomenon is referred to as a shadow education system. ${ }^{1}$ Bray (1999) justified the use of the metaphor of a shadow in the following way:

First, private supplementary tutoring only exists because the mainstream education exists; second, as the size and shape of the mainstream system change, so do the size and shape of supplementary tutoring; third, in almost all societies much more public attention focuses on the mainstream than on its shadow; and fourth, the features of the shadow system are much less distinct than those of the mainstream system (p. 17).

Private tutoring is a complex phenomenon since it may have various forms, involve numerous agents, and occur in a variety of contexts. Consequently, various definitions of the term are available in the literature on shadow education. In this article, private tutoring is understood as "tutoring in an academic school subject (e.g., mathematics, history, or English), which is taught in addition to mainstream schooling for financial gain" (Silova, Būdiene, \& Bray, 2006, p. 29). This definition of private tutoring includes private tutoring lessons (offered by individuals) and preparatory courses (offered by institutions). In the present study, however, the focus is on the former.

Concerning geographical dispersion, private tutoring is determined especially by cultural, educational, and economic factors. Bray (1999) suggests that private tutoring is likely to be widespread in Asian cultures, which place a strong emphasis on effort as a factor explaining and determining success. In contrast, European and

Apart from this expression, which is used in Western countries, there are country-specific terms traditionally denoting private tutoring: Buxiban in Taiwan, Hagwon or cram schools in South Korea, Yuku in Japan (Chung, 2019). 
North American cultures are more likely to emphasise ability and thus private tutoring is not so prominent there. Relatedly, Hamid et al. (2009) propose that in East Asia private tutoring assumes a position as an essential part of education, culture, and society, while in Anglophone and European countries it is principally remedial and supplementary in nature. Recent developments, however, show that, for example, private tutoring in Australia has grown immensely in response to neoliberal educational reforms, which have intensified competition in schooling (Sriprakash et al., 2016).

\subsection{Providers and recipients ${ }^{2}$}

Reflecting the changes in the mainstream education system, shadow education providers make tutoring readily available to potential recipients. The providers typically offer a number of modes of tutoring. The four main modes are as follows: one-on-one tutoring, small-group tutoring, lecture-type tutoring, either live or video-recorded, and online tutoring (Zhan et al., 2013, p. 498). The present study focuses on oneon-one tutoring, i.e. on situations in which a single tutor works with one tutee at a time.

Diversity may be found in the qualifications of tutors (Silova, Būdiene, \& Bray, 2006). Teachers are the main providers of private tutoring. Bray (1999, p. 37) distinguishes two situations: (1) tutors are teachers in the mainstream system who tutor their own students and receive additional payment; (2) teachers tutor students for whom they otherwise do not have any responsibility. Obviously, if the first situation is the case, it raises serious ethical issues. In recent studies, depicting such circumstances in Bangladesh and India, Hamid et al. (2009) and Chatterjee (2018) explain that poor teacher salaries are the reason for such practices since private tutoring yields an extra income. In some other countries, for example in Singapore or Morocco, tutoring one's own students is forbidden (Bray, 1999). Contrastingly, in the Czech Republic, the shadow education system is ignored by educational policy (Št'astný, 2016).

Apart from teachers, there is a considerable variety of tutors in the shadow education system in terms of age, qualification, employment status, workload, etc. An important cohort of tutors is that of university students, who, according to Zhan et al. (2013), often work as part-time tutors; they commonly supplement their incomes by tutoring secondary school students (Bray, 1999).

Private tutoring may be offered to recipients through a company or a self-employed tutor. Given the individualistic nature of learning nowadays (Biesta, 2006), some students may choose to respond to the supply and buy the service, i.e. private tutoring in a particular subject. The services that professionals provide are characteristically different from the goods that are sold by a manufacturer or a retailer in

2 Bray (1999) refers to the two groups of agents as "producers and consumers" (p. 37). 
62 that they are intangible and the purchaser has to take them on trust (Macdonald, 1995).

Regarding the choice to use private tutoring, Jokić et al. (2013) established a conceptual framework which places the previously defined decision concerning the use of private tutoring at the centre of the system.

This ecological system [...] is divided into five socially organised subsystems, representing a set of nested and interconnected structures that all have a potential to influence the decision and upon which this decision can have a reciprocal effect. These structures range from the immediate individual characteristics of the pupil to the most remote setting of the larger society (Jokić et al., 2013, p. 28).

The system is illustrated by five concentric circles; annuli represent individual subsystems: pupil, parents, school, educational policy, and society. In his theoretical study, Št'astný (2015, pp. 60-61) discusses this system and summarises the authors' assumptions leading to placing the previously defined decision at the centre of the scheme: (1) the decision usually depends on pupils or their parents; and (2) it is tightly linked to their attitudes to the educational system and educational aspirations. Following the framework of Jokić et al. (2013), the decision concerning the use of private tutoring is likely to be the result of complex interactions of the five subsystems.

Research findings show that those who engage in private tutoring are mainly students at the secondary level; the dominant group comprises students whose performance is already good, and who want to stay competitive (Bray, 1999). Frequently reported reasons for private tutoring include remedial or enrichment purposes (e.g. Zhan et al., 2013), and, also, securing an educational advantage (Sriprakash et al., 2016). The next part deals specifically with PTE; it shows which aspects of current PTE are of interest to researchers and provides a mosaic of findings.

\subsection{Private tutoring in English}

Yung (2019) asserts that research in the field of shadow education, particularly in language learning, is still in an infant stage. In 2009, Hamid et al. reported only two research studies that focused exclusively on PTE. Considering recent studies in this area, two major strands of research may be observed. The first one includes studies which investigate the effects of PTE on students' achievement in English (Andabati et al., 2018; Chang, 2019; Chaterjee, 2018; Hamid et al., 2009; Kim et al., 2016). These quantitative studies addressing the effectiveness of PTE relate students' participation in PTE to their academic achievement, i.e. their performance on various standardised tests. The studies investigate the phenomenon in the countries where shadow education has traditionally been an established enterprise ${ }^{3}$ (e.g. Hong Kong, Korea, Taiwan) or in less affluent countries, where it is believed to be a necessity

3 Research papers report considerable investments by families in private tutoring in wealthier East Asian countries, which amount to billions of dollars annually (Bray, 1999; Hamid et al., 2009). 
to compensate for the inadequacies of formal tuition in English (e.g. Bangladesh, Uganda). Interestingly, all the studies confirmed a positive effect of PTE and identified some other influential factors (Andabati et al., 2018; Chang, 2019; Hamid et al., 2009; Kim et al., 2016).

For example, Hamid et al. (2009) conducted a mixed-methods study in which they investigated PTE in Bangladesh, more specifically tenth-grade students' perceptions of PTE. In the quantitative part of their study, they analysed questionnaire data and the students' test results $(n=228)$. Multivariate logistic regression confirmed a considerable impact of PTE and disclosed the significance of some other variables (the mother's level of education and gender). Chang (2019, p. 86) emphasised that the strength of PTE became minimal when the self-study variables were added to the research - the time spent on self-study activities had a significant and positive effect on Taiwanese students' performance. Kim et al. (2016) investigated the effects of the time and cost of private tutoring on Korean students' achievement in English and mathematics. Concerning English, they concluded that in the Korean context it is likely to be effective to invest in the quality of tutoring, i.e. in a more costly service, since the cost of tutoring was significant in all models when the tutoring time, i.e. average hours a week spent for attending English and math tutoring, was held constant. Contrary to that, the tutoring time was not statistically significant (Kim et al., 2016, p. 253). Using structural equation modelling, Andabati et al. (2018) investigated the significance of private tutoring in improving English language literacy in learners in Uganda. They confirm the positive impact of PTE but also suggest several additional factors, such as age, gender, pre-school education, type of school, and household structure, which influenced the level of literacy.

The second strand of research in PTE aims at investigating learners' experience, attitudes, and motivations. There are few studies providing a better understanding of English language learners' participation in private tutoring. In the qualitative part of their study Hamid et al. (2009) interviewed 14 selected students out of a larger sample $(n=228)$. The analysis of the data uncovered the fact that the students perceived the quality of English teaching at schools as being poor, which made success in learning impossible to achieve without private lessons. Consequently, they saw PTE as imperative; in other words, PTE was not only socially desirable but also inevitable and, for some learners, even preferable since they did not believe in the quality of formal education.

In his study, Lee (2010) examined the English-learning experiences of the students in a university programme in detail and focused on the ways in which they were similar and different in terms of their English-learning backgrounds and proficiency. On the basis of the survey and in-depth interviews, seven cases out of 43 were selected for the study. The findings of the study suggest that the students' levels of English proficiency varied immensely even within the same programme because of their different private English learning experiences. Furthermore, these students reported diverse motivations and strategies for learning English outside school. 
Yung (2015) investigated Chinese learners' accounts of their PTE experiences and reflections on those experiences through narrative inquiry. The findings of the study suggest that the 14 participants upheld the importance of achieving communicative competence through PTE but at the same time accepted the fact that PTE was better equipped to address examination-oriented needs. In conclusion, they were comfortable with this seemingly contradictory view of PTE.

Another study by Yung (2019) is more specific since it focuses on the dynamic nature of student motivation during PTE. The study is the first attempt to analyse the L2 motivational selves (Dörnyei, 2009) of PTE learners through their language learning narratives. The findings suggest that learners receiving PTE possessed dominant ought-to L2 selves, suppressed ideal L2 selves, and insecure actual L2 selves. Their low self-efficacy and/or high aspirations to perform well in the public examination in their actual L2 selves created a discrepancy between their current and future L2 selves (Yung, 2019, p. 129).

Nevertheless, none of the studies which were discussed above investigated oneon-one tutoring; all of them focused on other types of private tutoring, especially on group formats including lecture-type supplementary tuition. This study focuses on one-on-one tutoring because of its significant features (Bleistein \& Lewis, 2015), namely providing personalised learning that cannot be achieved in larger language classrooms, addressing an individual's special strengths in a way that is impossible in larger classes, and creating space for learner agency. One-on-one tutoring is an organisational form that enables the implementation of teaching practices helping students to enact and enhance their agency in ways discussed, for example, by Larsen-Freeman (2019) including learner-driven feedback etc. From the perspective of PTE in the Czech Republic, the study explores an under-researched area (part 2.1). Another asset of the study is that it provides insights into PTE in the European context, which is also rare.

\section{Context of the study}

In the Czech Republic, English maintains the status of a foreign language, which means that learners of a foreign language learn a non-native language in the environment of their native language (Gass \& Selinker, 2008). Therefore, the characteristics of English language learning is this country correspond to those of foreign language learning as proposed by Cameron - "very little experience of the language outside the classroom, and encounters with the language (...) through several hours of teaching in a school week" (2001, p. 11). These characteristics apply to the majority of learners, though, obviously, there may be inter-individual differences.

Concerning formal education in the Czech Republic, the curricular reform in the first decade of the 21st century established a new system of curricular documents (Greger \& Walterová, 2007) including Framework Education Programmes for 
pre-school, basic ${ }^{4}$ (MŠMT, 2017), and secondary education (e.g. VúP, 2007). Schools in the Czech Republic are autonomous institutions; they construct their own School Education Programmes, which are in alignment with the respective frameworks. English, as a Foreign Language, falls within the educational area called Language and Communication through Language. The position of English among other foreign languages is prominent since it should be the first foreign language to be taught. Compulsory education in English starts in grade three, though it is possible to start earlier, depending on a school's vision and resources (MŠMT, 2017). Most commonly, there are three mandatory lessons of English per week in each year from grade three of basic school until grade four of secondary school. Thus, a typical secondary school graduate, excluding, for example, graduates from international schools, bilingual secondary schools, etc., has experienced three lessons of English a week for a period of 13 years before taking the school-leaving exam. The exam is known as the maturita exam. ${ }^{5}$ It is not competitive, since it does not regulate entry to prestigious study programmes. Czech universities often rely on other test providers, e.g. the SCIO company, ${ }^{6}$ administer their own tests, or do not require a test to be passed as a criterion for admission. In 2019, 84.5\% of all applicants for Czech universities were accepted for the 2019/2020 academic year (MŠMT, n.d.).

\subsection{PTE in the Czech Republic}

As regards the Czech Republic, little is known about the shadow education system in general, including PTE. Št'astný (2016) reports a certain lack of interest in this topic on the part of researchers, which is in contrast with recent trends in Asian countries and elsewhere in Europe. Therefore, his research project represents a substantial contribution to the body of research on shadow education in the Czech Republic. Though his research does not target PTE only, it sheds some light on private tutoring in this subject-specific domain.

The study by Št'astný (2016) uncovers the fact that $59 \%$ of the 465 secondary school students who took private lessons had experienced private tutoring in foreign languages, mainly in English. The students reported various reasons for participating in private tutoring, ${ }^{7}$ the most frequent being dissatisfaction with school results, preparation for the school-leaving exam, parents' decisions, and a desire to learn something beyond the curriculum (Št'astný, 2016). The reasons for students' participation in private tutoring were also the focus of Černá et al. (2016), who investigated

4 Basic education in the Czech Republic comprises primary and lower-secondary education (ISCED 1 and ISCED 2 levels).

5 Since 2011 the reformed maturita exam has been implemented. Nowadays it consists of a common (state) and a profiling (school) part. For the 2019/2020 school year the common part includes a mandatory exam in the Czech language and a mandatory exam in the first foreign language (i.e. mostly English) or mathematics, from which every testee is obliged to choose one.

6 More than 50 faculties in the Czech Republic use $\mathrm{SCIO}$ tests for admission procedures (SCIO, 2019).

7 Here private tutoring means tutoring in all kinds of subjects, foreign languages (English) and mathematics being the most frequent ones. 
66 the learning histories of Czech speakers ${ }^{8}$ of English and their achievement in selected communicative language competencies. The quantitative part of this mixed-methods study yielded data concerning individual students' participation in non-formal learning while at basic and secondary school. As regards individual students' involvement in PTE while at basic school, $28.6 \%$ of the 228 students took courses and/or private lessons. As for the reasons for their participation in PTE, the most frequent ones were related to the pleasure of learning English, remedial needs, advancement needs, and parental decisions. While at secondary school, $22.2 \%$ of all the students participated in PTE. The recurrent reasons for their involvement were related to exam preparation, remedial needs, and the pleasure of learning English (Černá et al., 2016, pp. 79-83).

Both studies confirmed the influence of parents' educational status on the involvement of their children in private tutoring (Černá et al., 2016, p. 88; Št'astný, 2016, p. 180). Otherwise, the findings of the two studies can hardly be compared because of conceptual differences; nevertheless, there is a considerable level of correspondence between the reasons for private tutoring, irrespective of the subject and the reasons for PTE.

Št'astný (2016) also explored the use of various organisational forms of private tutoring in the Czech context; the results indicate that individual lessons prevail (78\%) over small groups (22\%); however, the occurrence of small groups in PTE was much higher compared to mathematics (32\% vs. $15 \%)$. The author attributes the difference to the nature of the subject matter.

Furthermore, Št'astný (2016) also disclosed who the providers of private tutoring in the Czech Republic were. Most frequently, a teacher from a different school provided private tutoring (36\%). Among other providers, he also identified a native speaker and language agency tutor (6\%), who are specifically related to foreign language education.

In conclusion, PTE in the Czech Republic remains very much in the shadows. Therefore, this study aims to provide insights into the perceptions of those who consume PTE, its recipients.

\section{Method}

The present study is linked to previous research on individual learning histories in that it analyses a segment of data obtained earlier in the context of a large interdisciplinary study. More specifically, the study is based on recollective data elicited by means of narrative interviews (Creswell, 2011; Hendl, 2012) within an earlier research project (Černá et al., 2016). This article reports a secondary analysis of the data from a new perspective, i.e. a supplementary analysis (Heaton, 2008). In this

8 First-year students in the English language teacher education study programmes (i.e. successful learners of English) at three Czech universities (Palacký University in Olomouc, University of South Bohemia České Budějovice, and University of Pardubice) constituted the research sample. 
study an emergent issue of the data that was only partially addressed in the primary study, i.e. one-on-one tutoring in English, is analysed in greater depth.

The aim of this study is to uncover the nature of the PTE that the Czech students of English experienced from early childhood to their entry to the university and the perceived personal significance of this type of education in their lives.

Consequently, the following research questions were formulated:

1. What is the nature of the PTE that the students experienced?

2. How do the students perceive the role of private tutoring in their learning English?

The respondents in this study are Czech speakers of English at the onset of their university studies of English, i.e. on entry to bachelor's study programmes preparing students for English language teacher education study programmes at three Czech universities. The research sample included 20 respondents (Table 1), 13 females and seven males, ${ }^{9}$ who were purposefully selected from a larger group of 228 students according to the nature of their learning experiences. The selection procedure was based on questionnaire data, which enabled the researcher to divide the students into four groups. The first group included the students who learnt English mainly in a formal educational context; non-formal and informal learning was marginal in their lives. The second group involved the students who used English extensively outside the school for various purposes. The students in the third group learnt the language in a variety of contexts; they learnt English at school, attended private lessons and courses, used English outside the school, and travelled to English-speaking countries. Lastly, the fourth group comprised the students with exceptionally long residence in an English-speaking country. Moreover, each group had two sub-groups: the students whose attitudes toward English and learning English were positive all the time and the students whose negative attitudes had undergone considerable modifications in the course of their lives. After the students had been grouped, 20 respondents to be interviewed were chosen randomly from each group. The selection procedure was influenced by the unwillingness of some students to cooperate and by students' availability in the time period allocated to the interviews in the individual towns. After conducting a pilot interview, one researcher, the author of this paper, interviewed all the respondents at their universities in June and July 2014 and in February and March 2015. All the interviews were conducted in the Czech language, ${ }^{10}$ the students' mother tongue, in order to prevent potential problems stemming from the respondents' inability to produce an extensive narrative in English. All the students who were interviewed were given nicknames to protect their identity.

9 The ratio reflects the structure of the larger research sample in terms of gender.

10 The author translated the quotes which appear in this article with an attempt to preserve authenticity to the highest possible extent. 
68

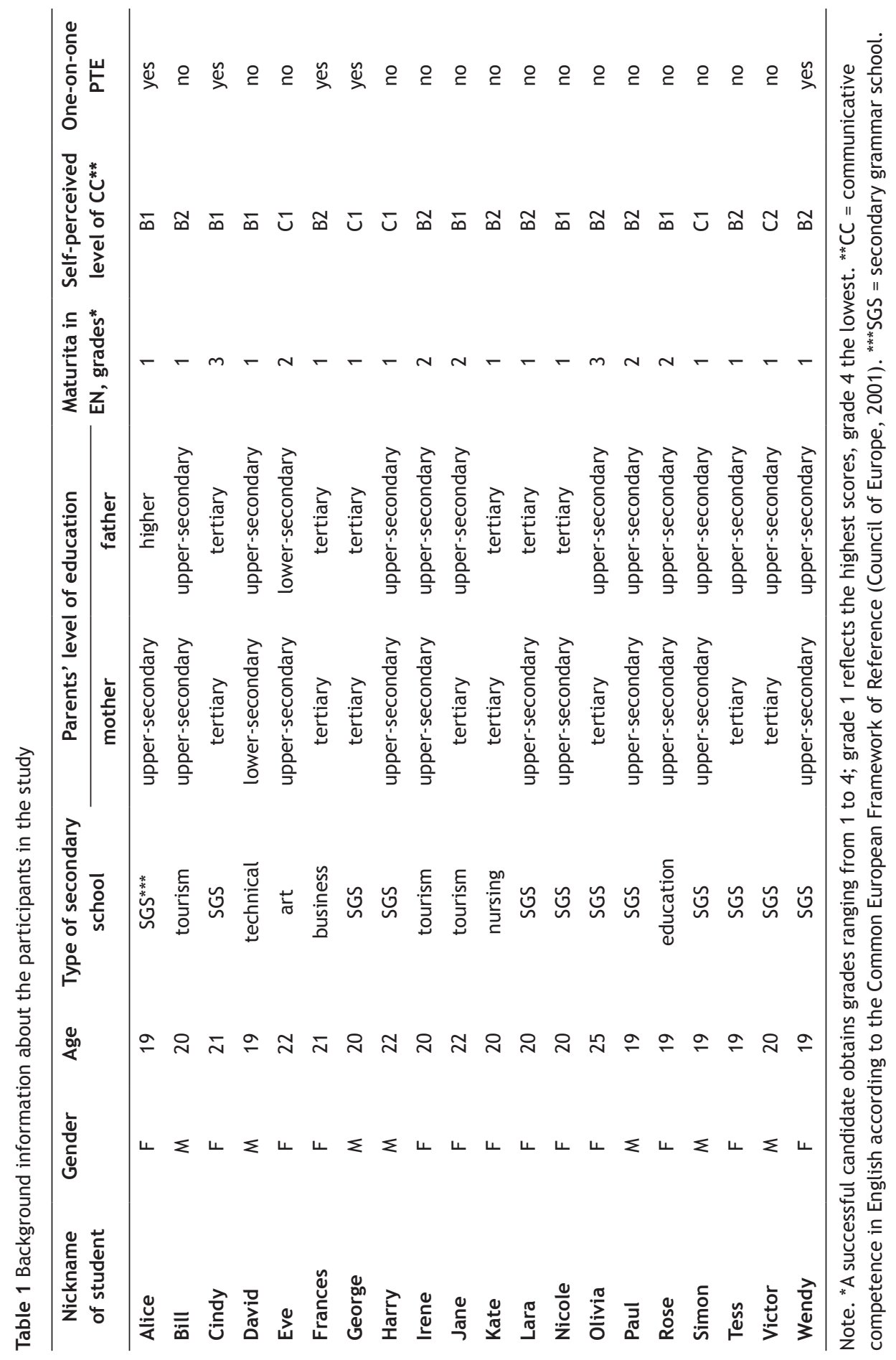


Apart from following general guidelines for interviewing, the researcher respected recommendations for conducting narrative interviews (Elliott, 2005; Hendl, 2012). After a short introduction, the researcher asked questions to elicit the main narrative, i.e. questions directed to specific times (the pre-school, basic school, secondary school, and post-secondary periods), and to specific situations (learning English in various contexts, including a non-formal context). If necessary, the researcher asked a question to learn more about a particular period in the interviewee's life, about a topic of interest, etc. In order to maintain the momentum of the interviews, the researcher implemented some strategies, e.g. using reinforcement feedback, attention-focusing devices, or various probes, recommended in the relevant literature (Dörnyei, 2007, pp. 142-143). All the interviews were audio-recorded; the average length of an interview was 50 minutes and 19 seconds.

Concerning the analysis, potential limitations of the secondary analysis (Johnston, 2014) were minimised considerably by the author's involvement in the primary study. The author of this paper was familiar with its context and procedures and collected and analysed the data. The process of the qualitative data analysis contained all the steps recommended by Creswell (2011). The recordings of the interviews were transcribed using commented transcription (Hendl, 2012). A single researcher using open coding supported by the Atlas.ti7 software conducted a subsequent analysis: after a preliminary exploratory analysis, the researcher analysed the data using the constant comparative method (Silverman, 2001). Categories were developed inductively through "comparing incidents in the data to other incidents, incidents to categories, and categories to other categories" (Creswell, 2011, p. 434). As regards the trustworthiness of the study, it builds on the credibility of the primary study, which was ensured by having an external audit conducted by an expert from outside the research team.

\section{Results}

The analysis of the interviews confirmed the individualised nature of learning nowadays. The study, however, identified a group of students for whom PTE was not directly relevant. None of them ever mentioned considering PTE as an educational option, even though indirect questions addressed the issue. ${ }^{11}$

Out of twenty informants, five people had used PTE in some period of their lives. The nature of the experience, however, differed in many aspects. The next part presents accounts of the individual respondents' experience of PTE in order to illustrate its nature, and then the answers to the research questions are provided.

11 Related limitations of the secondary analysis are further discussed in the Conclusion. 
Facing the school-leaving exam, which included English, Alice needed encouragement and reassurance: "...before the maturita exam I felt respect; I was afraid" $(2: 2)$. A series of ten lessons with a private tutor, which she called a course, was intended to help her gain confidence. Though she did not learn any new content "we revised this and that ... and he did not teach me anything new, we just revised" $(2: 5)$ - she obtained the support that she needed. Concerning PTE, it was just an episode in her life: "It was the only occasion on which I needed such help... otherwise there was no need for it" (2:7).

Similarly, approaching the completion of secondary school encouraged Frances to use PTE, though her reasons were different. One year before the school-leaving exam, Frances made the decision to study English at university. At the same time, she felt dissatisfaction with the English lessons at school: “... the teacher taught us just basic grammar... she did not explain any exceptions to the rule, [...] tests were very simple [...], during the lesson she asked us to talk in pairs and the students talked in Czech and about something totally different; she walked among them and said nothing, [...] she gave us easy tasks..." (7:7). Consequently, she realised that the school she was studying at would not prepare her for university: "I knew that with what we were learning at school I would not make it" (7:1). Then she found a private tutor, a university student in the study programme that Frances planned to apply for, to get her ready for the entrance exam. She attended private lessons twice a week for a year.

In her learning history, Cindy underwent several episodes of motivational fluctuations; whenever her motivation declined, it was in response to the harmful effects of the teacher or the learning experience (Černá, 2015). When this happened, her mother always did something to counterbalance her loss of motivation. Apart from assisting her daughter with home assignments or finding a penfriend, the main intervention strategy that she used was hiring a private tutor. It first happened when Cindy's marks in English became average in grade five after the arrival of a new teacher whose teaching style differed considerably from that of the previous one. Cindy was desperate about her school results, which defined the main aim of private lessons: "[the tutor] tried to prepare me for those tests in order to have better marks" (4:7).

Later, while at an eight-year secondary school, ${ }^{12}$ Cindy experienced a large class of learners. She felt that she had a limited chance to be active in English lessons: "My turn never came so that I could practise, so I had private lessons to improve in the language" (4:8). Initially, Cindy felt that she was being pushed too much by her mother to attend private lessons, but later started to appreciate her private lessons: “Without the extra lessons ... I wouldn't have been able to make progress" (4:4). At the same time, however, she perceived differences in the quality of individual

12 In the Czech Republic, most of the secondary school programmes last four years; however, there are exceptions, such as six-year or eight-year grammar school programmes - selected pupils enrol in such programmes after completing either five or seven years of their basic education. 
tutors' lessons: “it seemed to me that she [the second tutor] didn't know what to do with me ... as if she was waiting for me to tell her what I needed, but I didn't know it at that time" (4:10). Another tutor was much more successful in addressing Cindy's needs: "She prepared various tasks for me; I liked it; she also prepared listening tasks, which I didn't do with the previous tutor" (4:13).

Concerning Wendy, she started to attend private English lessons as a pre-schooler together with the son of her mother's friend. The lessons lasted for years and provided space for enrichment of the curriculum or for remedial practice: "In those private lessons we continued [with the subject matter] on and on, and we learnt something new and when there was a problem at school, we dealt with the problem" (21:7). Interestingly, she developed a pleasant friendship with her 'classmate', which motivated her to attend the private lessons: "We used to go to her [tutor's] place, and we both liked it, and we looked forward to seeing each other very much after a week" (21:10). While at secondary school, Wendy attended the lessons on her own, since there was a need to link the content of PTE to the lessons at school: "...we mostly did the same as we did at school to deepen my knowledge" (21:8).

Though different in many aspects, the experience of the four students with PTE shares a common characteristic: there is almost no mention about who the tutors were. The students mostly refer to them as "someone", "a man", "a woman", "a colleague of my parents", "an acquaintance of my parents", "a (university) student". The only exception was Frances, who, having found her tutor herself, knew exactly who she was. None of the respondents used the word "teacher" when explaining who provided the private lessons.

Unlike the previously mentioned students, George went through a substantially different experience with PTE, since his tutor was a native speaker of English, more specifically a middle-aged American woman. George is a successful learner of English who started to learn the language as a pre-schooler and also went on a number of courses. While at an eight-year secondary school, he was critical of his English teachers and their lessons. At the same time, he studied English autonomously and even provided PTE to his peers. He was active in searching for opportunities to communicate in English and, therefore, he hired the native speaker tutor. His aims were quite clear; he sought to improve his speaking, especially pronunciation and pragmatic aspects of communication. Furthermore, he was interested in learning about the culture of the US.

During an introductory lesson, however, the intended private tutoring changed into a reciprocal service. "I attended the first lesson of conversation. I was there and we talked and enjoyed each other's company [...] then it progressed in the way that I taught her Czech and she taught me English, so nobody paid anything" (8:3). George appreciated this arrangement since paying by this reciprocal service enabled him to save a sum of money per lesson which he considered relatively high at that time. He was the only respondent who mentioned financial aspects of PTE.

In the course of time, George's relationship with the American tutor changed into a friendship: "And then we made friends, also with her family, with her son, who is 
72 also an American, and we sometimes visited each other, went for dinner, or whatever..." (8.4). Thus, George's contacts with the American family became motivated by social relationships, which the English language mediated: "We often used to go out together [...] so, we spent a lot of time together and he was a native speaker, whom I used to see a lot... not as a teacher, but it was conversation, wasn't it?" (8:5). Apart from having a companion, George acknowledged that "thanks to him I certainly learnt a lot" (8:6).

\subsection{The nature of PTE}

In response to the first research question, the nature of the PTE that the respondents experienced in their lives will be discussed in terms of intensity, reasons, recipients, providers, and the decision to use it.

The intensity of the PTE varies from short-term (a series of lessons), to long-term events (years) depending on the reasons individuals have for using it. Those may be clearly defined, e.g. preparation for an exam (Alice and Frances), or may be variable and responsive to changing circumstances (Cindy and Wendy). The reasons for PTE, as they were identified in the respondents' narratives, reflected their cognitive, affective, and social needs in a particular phase of formal education. Cognitive needs seem to have been more relevant for Frances, Cindy, and Wendy while she was a secondary school student. Affective needs are discernible among Alice's reasons for PTE. Social needs gradually gained importance for Wendy, when a social relationship with another pupil motivated her to participate in PTE, and for George, whose relationship with the family of his American tutor outweighed the learning outcomes.

Both basic and secondary school learners become recipients of PTE, Cindy and Wendy started to take private lessons as primary ${ }^{13}$ school learners.

Concerning the providers of PTE, the analysis uncovered the fact that they are very much hidden in the shadows; little is known about their qualifications and expertise since the respondents mostly used various indefinite expressions to refer to the tutors and did not provide specific information. This may have several causes; for example, for a variety of reasons, the respondents did not possess information about the tutors' qualifications and/or educational background or, given the nature of the study, they did not remember it. The question is whether the parents who initiate the use of PTE consider providers' qualifications or not. In spite of being in the shadows, the providers enjoy the trust of those who buy their services - they are called to action to remedy problems which originate within the mainstream system (see Cindy's reasons for PTE), or to substitute for some of the responsibilities of the mainstream system (e.g. preparation for the school-leaving exam, as in Alice's case).

Native speakers of English represent a group of tutors that is specific to the field of foreign languages. Considering George's reasons for finding a native speaker tutor, they perfectly match the assets that native speakers bring to foreign language

13 In the Czech Republic, primary school is the first stage (grades 1-5) of the so-called basic school. 
classrooms, i.e. communicative competence in English and knowledge of the target culture.

As regards the decision to use private tutoring, in the present study, it was the parents who decided to use PTE when it concerned a primary school pupil. This was evident in Cindy's and Wendy's accounts. While at secondary school, the students made the decision themselves, presumably with their parents' financial and other support - with the exception of George, nobody even mentioned the costs of the service.

\subsection{The role of PTE in the students' lives}

Concerning the second research question, it may be concluded that the Czech students in the present study who experienced PTE perceive its role as positive, with occasional reservations, and appreciate its impact on their learning of English and also on their social relationships.

Furthermore, PTE assumed different roles in the respondents' lives. PTE is supplementary in the sense that it provides what the mainstream system fails to provide (Alice, Frances, Cindy, Wendy) or supplementary, indicating that it provides additional space for learning which is not, for some reason, available in the mainstream system (Wendy, George).

Noticeably, the five students' participation in PTE is related to formal learning of this language. In the cases of Alice, Frances, Cindy, and Wendy their involvement in PTE really shadowed the mainstream education system: the shadow system reacted flexibly to students' needs that were triggered in the formal system. For George, self-initiated PTE opened up a space for progress which the mainstream system could not provide.

There were students, however, in whose lives PTE did not assume any direct role. On the basis of the similarity of their histories, two groups of students may be identified.

Rose, Lara, and Paul learnt English predominantly at school. Rose enjoyed every aspect of her schooling, something she repeated many times during the interview. She considered herself a successful learner of this language since her success in communication with foreigners outside school confirmed her competence. Similarly, Paul succeeded in learning English at school and he was able to communicate with native speaker teachers. Even before the maturita exam he passed an international exam, which certified the B2 level of proficiency in English. Lara was different in that she was not satisfied with her teachers of English. Her dissatisfaction was not limited to English but concerned the school she was attending at that time. Her parents took action and encouraged her to attend a different school, which brought about a change for the better, including English.

The rest of the group perceived English as a medium of communication or a tool to achieve something rather than a school subject to learn. This was reflected in their use of English in their everyday lives in a range of activities. While some of 
74 them were successful learners at school, some others were not, but it did not seem to matter. Some students were proactive in finding opportunities to communicate in English face to face or online. For Irene, Bill, and Simon, what was substantial in their lives was communication with native speakers. Bill and Simon, similarly to George, developed personal relationships with their former native speaker teachers. Irene enjoyed her lessons with a native speaker teacher on an intensive course after leaving her secondary school. Being able to communicate gave her confidence and provided motivational incentives for further study of English at a university, which she had never planned before. The priority of some other students was to use English for accomplishing different goals. For example, Harry, David, and Victor constituted a group of online gamers - their goal was to gain access to a more prestigious online group of gamers thanks to a better command of English. Tess and Kate went through extensive periods of exposure to English when they watched online videos and TV series in response to their personal interests. Jane and Eve linked their learning English with staying abroad. Following her sister, Eve left for England and spent several months and then several years working as an au pair and learning English there. Enchanted by a school trip to Scotland, Jane repeatedly returned there for summer.

The analysis of these students' narratives suggested that either the formal system did not trigger incentives that would give rise to the decision to use PTE or the action that was taken pursued a different direction. This concerns Lara, whose dissatisfaction with the way her teachers taught had a negative influence on her attitudes towards English and learning English, which might have been detrimental for learning in the future. Though there was an option to hire a private tutor, neither Lara nor her parents made this decision. They considered her English-related problems in the context of her schooling and encouraged Lara to apply for a different school, which eventually solved the problem. The second example is Eve's story. Similarly to Lara, she was not satisfied with the turnover of English teachers and with their teaching styles. This situation, in her opinion, made her an unsuccessful learner. While Cindy's mother immediately hired a private tutor in such a situation, Eve's parents did not. Because of their level of education, their expectations concerning their daughter's school achievements might have been lower. The significant figure in Eve's life was her sister - she always inspired Eve, who followed the steps she took, including the decision to travel to England and to live there.

\section{Discussion}

The findings of the study concerning the decision to use private tutoring correspond to the framework of Jokić et al. (2013) or, more specifically, to the underlying assumptions upon which the framework is built: the decision usually depends on pupils or their parents and is closely linked to their attitudes to the education system and educational aspirations. 
The study uncovered a group of students who decided not to use PTE as an educational option because of the lack of reasons or pursuing different paths. The reasons for using PTE of those who engaged in it correspond with the literature on shadow education, which distinguishes remedial or enrichment purposes of private tutoring (e.g. Zhan et al., 2013). However, securing an educational advantage (Sriprakash et al., 2016) did not appear among them. It might be linked to the fact that the maturita exam is not competitive and it may even have a negative backwash effect on a segment of the secondary school population because the exam is at a lower level than the expected outcomes of some programmes. Thus, secondary grammar school students, unlike students of other types of secondary schools, aim at the B2 level (VúP, 2007) while the maturita exam in English is at the B1 level (CERMAT, 2014).

Private tutoring is rather associated with secondary school students (Bray, 1999; Št'astný, 2016). Two students in this study became recipients of PTE as primary school learners. This may be attributed to the specific features of learning English, because parents, who usually help their children while they are at primary school, do not feel confident enough to assist them with English. This necessitates external tuition. Cindy's mother, a beginner in English, took some lessons together with her daughter. Being aware of the role of English in today's society, Wendy's parents initiated PTE as a free time activity, which later served remedial purposes. They were not able to help their daughter since they spoke other languages but not English.

The findings of the study show how specific and important native speaker tutors are. They are typically hired because of the assets they bring to teaching and learning English (Medgyes, 1999), which match those described by George. Native speakers tend to establish a less formal tutor-learner relationship, which was apparent in George's story as well as in those of Bill and Simon. Though they did not engage in PTE, they developed a personal relationship with their former native speaker teachers. They would meet them informally to talk about their shared interests. For Irene, her native speaker teacher on a post-maturita course was an important source of the motivation for learning English that she eventually found. The students perceived the ability to communicate with native speakers as a kind of certificate of their communicative competence. Furthermore, they appreciated the opportunity to develop pragmatic aspects of communication in English (e.g. using different registers, discourse management strategies).

The outcomes of the study may be compared to the findings of those studies which also focus on individuals. Hamid et al. (2009) conclude that students, being critical of the formal educational system, considered it impossible to achieve success in English without PTE. In the Czech context, however, all the students managed to be successful - all of them were accepted to study English at a university. Some of them benefited considerably from PTE either in the short term or long term. PTE reacted flexibly to the students' needs and provided individualised instruction, which is one of the main assets of one-on-one tutoring (Bleistein \& Lewis, 2015). In Cindy's case, one tutor failed in this respect, as she seemed unsure what to do. Cindy, a lower-secondary learner at that time, did not know it herself. This could 
76 be caused by unshared differing expectations on the part of both parties, which is a challenge for one-on-one tutoring (Bleistein \& Lewis, 2015). The space for learner agency, i.e. for actively guiding the learning process, remained unused simply because Cindy was not ready for it. This shows how a potential benefit of one-on-one tutoring may easily become a drawback.

This instance of a tutor-learner mismatch may also be discussed in terms of tutors' qualifications. Unfortunately, details about this particular tutor are unknown, but her not knowing what to do to help the learner may be attributed to her lack of communicative competence in English, lack of knowledge about the language, about teaching and learning, etc. (cf. Shulman, 1987). Thus, incompetent action or none at all makes tutees vulnerable, especially in an emergency when tutoring for remedial purposes is needed. Bleistein and Lewis (2015, p. 23) propose that qualifications for tutoring comprise three components: formal qualifications, experience, and personal qualities. Concerning formal qualifications, they do not provide any normative suggestions; their recommendations emphasise the importance of a tutor-learner match for a particular context. This was obviously not catered to in the above-mentioned case.

The other qualitative studies that were mentioned in this article (Lee, 2010; Yung, 2015, 2019) focus on different aspects of PTE than this study, which makes it impossible to compare the results. At the same time, they provide inspiration for future research (Yung, 2019).

\section{Conclusion}

The study sheds some light on PTE in the Czech context by uncovering the perspectives of its recipients. The findings of the study suggest that PTE supplements formal education in the course of the respondents' lives, including early childhood. Furthermore, the findings show that children's involvement in supplementary PTE is initiated either by their parents or by the children themselves for a variety of purposes that reflect their cognitive, affective, and social needs. The shadow education system is able to react flexibly to those needs when they arise. Concerning those who provide PTE, they constitute a diverse group that includes both native and non-native speakers of English; nevertheless, this study did not uncover anything about their qualifications, educational background, and/or expertise, or about the quality of their services. According to the study, the nature of tutoring tends to be considerably different if the tutor is a native speaker - apart from the perceived impact on their communicative competence, some learners, for example, built a strong relationship with the tutor, which they eventually valued more than the learning gains. In the other learners' lives, the role of supplementary PTE is linked to remedial or enrichment purposes.

The study identified two specific features of PTE. First, there is a demand for private tuition in English for primary learners for both remedial and enrichment 
purposes, which is not so common for other subjects (Bray, 1999; Št’astný, 2016).

This is because English is part of the primary curriculum and not all parents are able to assist their children if necessary. In addition, attending extra lessons in English is a popular free-time activity. Second, there is the native speaker tutor phenomenon. Native speakers constitute a specific group of English tutors, their main contribution being their communicative competence and knowledge of the target culture. Given the current emphasis on communication, this is especially valued, together with the lower formality of the tutoring situation.

The study did not shed light on the providers of PTE, who remain hidden in the shadows. Causes may be searched for among the limitations of the secondary analysis (Johnston, 2014); specific information concerning tutors was not collected for the primary analysis since PTE was not the focus - it emerged as an interesting issue to explore. Furthermore, deploying narrative interviews as a means of data elicitation presupposes a focus on the respondents' perception of events rather than on mere facts. Moreover, the participants are likely to recall recent events more precisely than those that happened in the remote past. Therefore, designing a study with a focus on private tutors of English is necessary in order to gain insights into who they are.

Another reason for not learning much about private tutors may be related to the fact that they are not in the focus of the Czech society, including, for example, educational policy, the media, and those who purchase private tutoring. This corresponds to Bray's (1999) claim that "in almost all societies much more public attention focuses on the mainstream than on its shadow" (p. 17). Consequently, it raises a significant issue to consider, the issue of trust. While teachers in the mainstream system are often subject to systematic criticism, which often tends to slip into denigrating the representatives of the teaching profession and the system (Tuma et al., 2020), eroding trust does not concern private tutors, who are protected by the shadows. Thus, addressing this issue might be another desirable direction for future research.

\section{Literature}

Andabati, D. C., Mukoki, J., Ashaba, C., Jehopio, P. J., \& Kyasiimire, B. (2018). Private tutoring in improving English language literacy: A structural equation modelling approach. Multidisciplinary Journal for Education, Social and Technological Sciences, 5(2), 1-18.

Biesta, G. J. J. (2006). Beyond learning: Democratic education for a human future. Boulder: Paradigm Publishers.

Bleistein, T., \& Lewis, M. (2015). One-on-one language teaching and learning. London: Palgrave Macmillan.

Bray, M. (1999). The shadow education system: Private tutoring and its implications for planners. Paris: International Institute for Educational Planning.

Cameron, L. (2001). Teaching languages to young learners. Cambridge: Cambridge University Press. 
78 CERMAT. (2014). Katalog požadavků zkoušek společné části maturitní zkoušky platný od školního roku 2015/2016. Anglický jazyk. Retrieved from https://maturita.cermat.cz/files /files/katalog-pozadavku/AJ_Katalog_pozadavku_MZ-17-18.pdf

Chang, C. H. (2019). Effects of private tutoring on English performance: Evidence from senior high students in Taiwan. International Journal of Educational Development, 68, 80-87.

Chaterjee, J. (2018). Do private tutors enhance English language ability? Regression discontinuity evidence from a policy experiment in India. Bulletin of Economic Research, 70(2), 139-149.

Council of Europe. (2001). Common European Framework of Reference for Languages. Cambridge: Cambridge University Press.

Creswell, J. W. (2011). Educational research. Planning, conducting and evaluating quantitative and qualitative research (4th ed.). Boston: Pearson.

Černá, M. (2015). Motivation in language learning: Focus on individual learners' stories. In M. Černá, J. Ivanová, \& Š. Ježková (Eds.). Learner corpora and English acquisition (pp. 143-160). Pardubice: Univerzita Pardubice.

Černá, M., Hornová, L., Ivanová, J., \& Ježková, Š. (2016). Routes and destinations. Learning histories of Czech speakers of English and their achievement in selected communicative language competences. Pardubice: Univerzita Pardubice.

Díaz, N. R. (2015). English private tutoring in France: the race for a better job starts in advertisement campaigns. Procedia - Social and Behavioral Sciences, 173, 176-180.

Dörnyei, Z. (2007). Research methods in applied linguistics. Oxford: Oxford University Press.

Dörnyei, Z. (2009). The psychology of second language acquisition. Oxford: Oxford University Press.

Elliott, J. (2005). Using narrative in social research. London: SAGE Publications.

Gass, S., \& Selinker, L. (2008). Second language acquisition: An introductory course. London: Routledge.

Greger, D., \& Walterová, E. (2007). In pursuit of educational change: the transformation of education in the Czech Republic. Orbis scholae, 1(2), 11-44.

Hamid, M. O., Khan, A., \& Islam, M. (2018). The spread of private tutoring in English in developing societies: exploring students' perceptions. Discourse, 39(6), 868-886.

Hamid, M. O., Sussex, R., \& Khan, A. (2009). Private tutoring in English for secondary school students in Bangladesh. TESOL Quarterly, 43(2), 281-308.

Heaton, J. (2008). Secondary analysis of qualitative data: an overview. Historical Social Research, 33(3), 33-45.

Hendl, J. (2012). Kvalitativní výzkum. Praha: Portál.

Johnston, M. P. (2014). Secondary data analysis: A method of which the time has come. Qualitative and Quantitative Methods in Libraries, 3(3), 619-626.

Jokić, B. (Ed.). (2013). Emerging from the shadow: A comparative qualitative exploration of private tutoring in Eurasia. Zagreb: NEPC.

Kim, M. S., Paik, I. W., \& Ihm, J. J. (2016). Do time and cost students spend on private tutoring contribute to improving their achievement in English and mathematics? KEDI Journal of Educational Policy, 13(2), 245-258.

Larsen-Freeman, D. (2019). On language learner agency: A complex dynamic systems theory perspective. The Modern Language Journal, 103, 61-79.

Lee, B. (2010). The pre-university English-educational background of college freshmen in a foreign language program: a tale of diverse private education and English proficiency. Asia Pacific Educational Review, 11, 69-82.

Macdonald, K. M. (1995). The sociology of the professions. London: SAGE.

Medgyes, P. (1999). The non-native teacher (2nd ed.). Ismaning: Max Hueber Verlag.

MŠMT [Ministry of Education, Youth and Sports]. (2017). Rámcový vzdělávací program pro základní vzdělávání (verze platná od 1. 9. 2017) [Framework education programme for basic education]. Retrieved from http://www.msmt.cz/file/43792/ 
MŠMT. (n.d.). Přijímací řízení ke studiu na vysoké a vyšší odborné škole. Retrieved from http:// www.msmt.cz/vzdelavani/skolstvi-v-cr/statistika-skolstvi/prijimaci-rizeni-ke-studiu-navysoke-a-vyssi-odborne-skole-1.

SCIO. (2019). Přehled fakult s Národními srovnávacími zkouškami. Retrieved from https:// www.scio.cz/nsz/fakulty/.

Shulman, L. S. (1987). Knowledge and teaching: Foundations of the new reform. Harvard Educational Review, 57(1), 1-21.

Silova, I., Būdiene, B., \& Bray, M. (Eds.) (2006). Education in a hidden marketplace: Monitoring of private tutoring. New York: Open Society Institute.

Silverman, D. (2001). Interpreting qualitative data. Methods for analysing talk, text and interaction (2nd ed.). London: SAGE.

Sriprakash, A., Proctor, H., \& Hu, B. (2016). Visible pedagogic work: Parenting, private tutoring and educational advantage in Australia. Discourse, 37(3), 426-441.

Št'astný, V. (2015). Fenomén soukromého doučování pohledem společenskovědních disciplín a teorií. Studia paedagogica, 20(1), 45-66.

Št'astný, v. (2016). Fenomén soukromého doučování jako stínový vzdělávací systém v České republice [Doctoral dissertation]. Available from https://dspace.cuni.cz/handle/20.500 $.11956 / 83694$.

Tůma, F., Píšová, M., \& Černá, M. (2020). Eroding trust in teacher professionalism: An ethnomethodological analysis of radio interviews with Czech experts on education. Studia paedagogica, 25(2), 47-69.

VúP [Institute for Research in Education]. (2007). Rámcový vzdělávací program pro gymnázia. [Framework education programme for upper secondary general education (grammar schools)]. Praha: VúP.

Yung, K. W. H. (2015). Learning English in the shadows: Understanding Chinese learners' experiences of private tutoring. TESOL Quarterly, 49(4), 707-732.

Yung, K. W. H. (2019). Exploring the L2 selves of senior secondary students in English private tutoring in Hong Kong. System, 80, 120-133.

Zhan, S., Bray, M., Wang, D., Lykins, C., \& Kwo, O. (2013). The effectiveness of private tutoring: students' perceptions in comparison with mainstream schooling in Hong Kong. Asia Pacific Educational Review, 14, 495-509.

Doc. PaedDr. Monika Černá, Ph.D. Department of English and American Studies

Faculty of Arts and Philosophy University of Pardubice Studentská 84

53210 Pardubice, the Czech Republic monika.cerna@upce.cz 